\title{
Strategy and Innovation of Mushroom Business in Rural Area Indonesia: Case Study of a Developed Mushroom Enterprise from Cianjur district, West Java, Indonesia
}

\author{
Rendi Febrianda ${ }^{1}$, Hiromi Tokuda ${ }^{2}$ \\ ${ }^{1}$ Graduate School of Bioresources, Mie University, Japan \\ ${ }^{2}$ Bioresources Faculty, Mie University, Japan \\ Correspondence: Rendi Febrianda, Graduate School of Bioresource, Mie University, Tsu City Kurimamachiyacho 1577, \\ Mie Prefecture, Japan.
}

Received: March 27, 2017

doi:10.11114/ijsss.v5i6.2304
Accepted: May 8, 2017 Available online: May 13, 2017

URL: https://doi.org/10.11114/ijsss.v5i6.2304

\begin{abstract}
Mushroom farming has become attractive business in agricultural sector due to its simplicity and flexibility of cultivation and quite profitable. Health awareness of Indonesian people about mushroom gives a positive impact to mushroom business. Behind the good aspects, several evidence argued that production performance of mushroom business is not optimal related to less capacity and deficiently appropriate knowledge. This paper aims to learn the unique strategy and innovation from local mushroom enterprise which is very famous in Cianjur distric, West Java, Indonesia in order to improve the business performance. Using technological (innovation) approach and qualitative method, this study concluded that there are two types of strategies, one relating to the technological part, and the other relating to the organization part. The technological focuses on attracting market and enhancing the yield productivity. The organization part focuses on developing capacity to fulfill the demand by making a contract agreement resembling contract farming with local society. For local society, the contract agreement has benefit to minimize both market failure and production problems under supervison support and without monopoly action. The strategies were capable of being successful innovation by interacting and cooperating with external sources, and performing certain adjustment with local condition.
\end{abstract}

Keywords: mushroom farming, mushroom enterprise, mushroom business, innovation, contract farming

\section{Introduction}

The growth of urban areas results in not only urbanization movement, but also in the tendency of workers moving to urban areas, withdrawing from the agriculture sector. This is a common phenomenon seen in Indonesia. One of the agricultural commodities which can be considered quite promising in Indonesia is mushroom, in which many mushroom producers turn into potential Small and Medium Enterprises (SMEs). Belonging to vegetables category, mushroom is valued for its high quality protein, excellent unsaturated fatty acids, high content of some vitamins, highly tradable commodity and the advantage of short harvesting periods as well as easy-to-use technologies (Marshall \& Nair, 2009 ; Amuneke et al., 2011). Despite the Indonesian society's awareness of health benefits of mushroom has resulted in the positive progress of the commodity, its demand is not responded optimally owing to problems related to the performance of mushroom SMEs (Nugroho, 2013). From Food and Agriculture Organization (FAO) data, national production of mushroom in Indonesia still reveals a positive trend even though it is fluctuated, as figure 1 shows.

West Java province occupies the first rank of national mushroom production by total $25,194,471 \mathrm{Kg}$ or $67 \%$ of national production in 2014 (Kementerian Pertanian, 2015). Cianjur as a well-known district located in the West Java Province Indonesia, is considered as the central area for mushroom production. The district has 350.148 hectares of total area in which 62.99\% of the population employed in the agricultural sector (Badan Pusat Statistik Kabupaten Cianjur, 2015). Cianjur district is currently famous for not only its fragrant rice but also its mushroom production. Most of Cianjur distric are mountainous areas and indeed fit with mushroom's natural habitat. However, natural condition is not sufficient from the business perspective. For increasing the yield, an appropriate method is important, while for business development, an appropriate strategy and innovation is essential. 


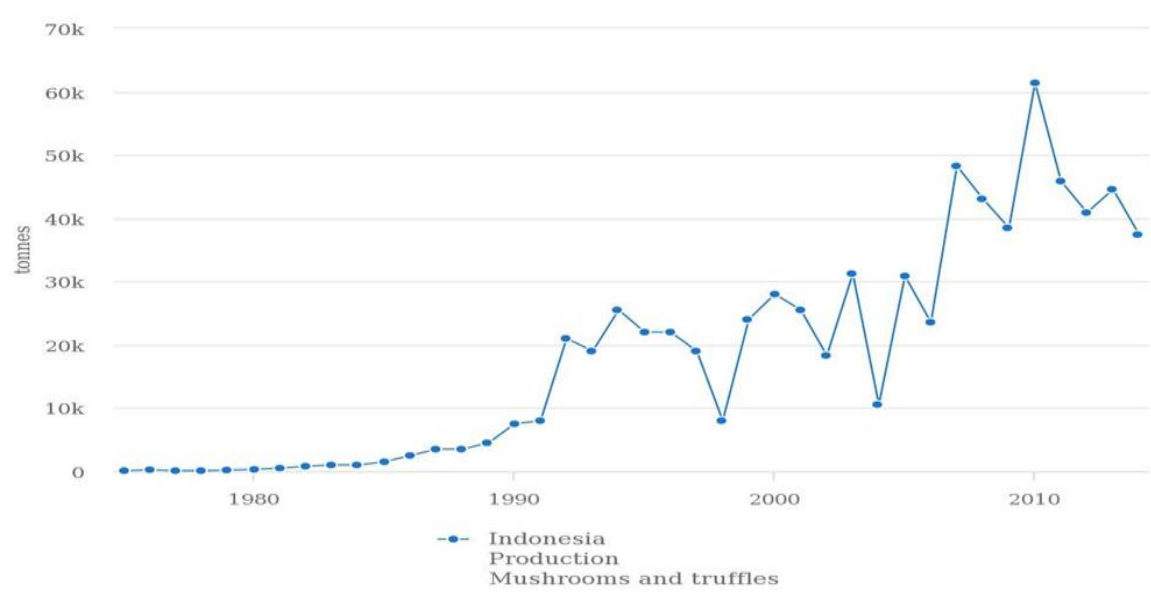

Figure 1. Trend of national production of mushroom \& truffles commodity in Indonesia (1975-2014)

Source : http://www.fao.org/faostat/en/\#data/QC/visualize

Table 1. Mushroom total areas and production development in Indonesia

\begin{tabular}{lcc}
\hline Year & \multicolumn{2}{c}{ Mushroom } \\
\cline { 2 - 3 } & Total Areas (Ha) & Production $(000 \mathrm{Kg})$ \\
\hline 2011 & 497 & 45,854 \\
2012 & 575 & 40,886 \\
2013 & 584 & 44,565 \\
2014 & 586 & 37,410 \\
\hline
\end{tabular}

Source : Statistical report of Kementerian Pertanian, 2015

As shown from Table 1, during 4 years (2011-2014), even though total areas are able to increase, the productions are dissimilar. Many empirical arguments said that lack of appropriate training and yield performance are the reason to the reduction of production. There are slight of research evidences to support the hypothesis, however few local studies have examined the business development of several SMEs of mushroom and mushroom farming in Indonesia. Those authors analyzed the problems and formulated business development strategies using SWOT analysis. The first major weakness is that mushroom enterprises have no sufficient capacity to meet the demand and have therefore to expand their production. The second is that inadequacy of technological performance influencing yield productivity (Nugroho, 2013 ; Arminsyurita, 2014 ; Iriantinah, 2014). By using the same tool of analysis, outside Indonesia, other authors also stated that mushroom industry such as in Malaysia and Turkey experience similar weakness (Celik \& Peker, 2009 ; Rozmiza et al., 2016). Eventually these previous studies suggested to expand the scale and also to enhance technological aspect for gaining quality and quantity of production.

The question is how to enhance these aspects. In Cianjur district, there is a mushroom enterprise which turned out to has a unique strategy and has been dominating about $70 \%$ of the mushroom market in Cianjur and even able to obtain the achievement performance or award in 2009. In this paper, this mushroom enterprise's initials is AAC. This paper specifically aims to study, from the enterprise's performance, the strategies and innovations which is successfully introduced to improve the business development, and how to implement them.

\section{Method}

According to Joseph Schumpeter (1934), innovation implies the creation of new products or qualitative improvement in existing products, the use of new industrial processes or creation of new market openings, or the development of new raw-material sources and other new inputs or forms of industrial organizations. Schumpeter indicated that inno vation is essential driver to seeking more profit.

Innovation itself has many kind of types, one of the dimension most commonly used to categorize innovations is radical or incremental dimension by Freeman and Perez. Radical innovation is an innovation that is very new (to the world, to industry, or to enterprises) and different from prior solutions, while incremental innovation is an innovation that makes minor changes or adjustment to existing practices. An incremental might has been previously known by the enterprise or industry (Schilling, 2012). 
Mushroom farming is quite different from common farming, as mushroom has no chlorophyll, it does not need much sunlight and can be cultivated indoors using a growth medium culture in cylindrical plastic packs which is called by Indonesian people as baglog. The reliability of baglog technology is the key of the business. Systems of innovation can be defined on several levels where this paper adopts technological (innovation) systems approach. A technological system is defined as networks of actors interacting in a specific technology area to generate, diffuse and utilize technology (Carlsson \& Stankiewicz, 1991). A technological system has a focus on a particular technology and its social networks. The boundaries and attention of technological system has been paid to the strategic actions of individual enterprise. The technological systems approach also pays attention to institutions, which can be actors's action and interaction including common habit, established practice, standards and so on. This study will be distinguished into two main elements, which make up technological system: actors and their competencies connected in networks, and institutions.

This paper is based on a single case study, and uses narrative style to explain the qualitative data of the mushroom enterprise AAC from Cianjur district. The data for 2015 are obtained through observations and in-depth interviews with the owner and field manager, the key persons of the enterprise, based on technological system framework, then some of which are validated by secondary data. The interview as well were conducted with mushroom farmer. The secondary data comprise some reliable online and printed news as the enterprise has already gained fame, especially in Cianjur district and then collaborated with related previous studies. This study has 3 limitations on which (1) research findings are only from the standpoint of respondents, (2) we focus on oyster mushroom (Pleurotus sp) crop type, which is widely consumed and dominates all mushroom markets in Indonesia, and, further, (3) we focus on how to produce the fresh mushroom product, not the processed product. The plot of this study can be divided into two parts: (1) identification of the type of innovation, and (2) analysis of how the innovations are built and implemented.

\section{Outline of the Owner and Enterprise}

This paper names simply the leader and CEO of AAC as the owner. The owner started learning mushroom science since he took his bachelor degree. After graduated, he became a research staff at center for food technology development in Bogor and learned much about food and mushroom development. Furthermore, the owner also used to work for big mushroom enterprise in Southeast Asia for 6 years until served as farm manager. In 1999, he decided to quit and tried to start his own business by hooking his co-worker from the previous enterprise.

AAC is the enterprise which serves as a producer. The one who produce the baglog and conduct the cultivation is called producer and the other who only cultivate baglog is called farmer. AAC is located in Salahuni village, Cianjur district, and was established in 2003, and since then has gained several achievements: two study visits by the Indonesian Minister of Agriculture in 2009 and 2010; the Food Security Award in 2009; invitations to speak at oyster mushrooms workshop in 2008 and oyster mushroom cultivation training in 2009; and to be a CEO and speaker at the Entrepreneurial E33 Force Development Forum in 2010. These events are conducted by government, agriculture magazines and academic institutions. $\mathrm{AAC}$ has 70 employees and 30 contract members as farmer. AAC has 3 hectares of total owned land areas, with 6 tons of fresh mushroom and 7000 baglogs of total production per day. The market covers Cianjur, Jakarta, Bogor, Sukabumi, and some areas in West Java Province. Overall AAC provides mushroom cultivation equipment and supplies, mushroom seedling, mushroom baglogs, fresh and dried mushroom, and mushroom cultivation training.

\section{Results and Discussion}

\subsection{Types of Innovation}

\subsubsection{Technological Innovation}

In general, even if mushroom is grown in a closed building, the problem of pest attack, for example, from insects, still remains. Thus, AAC developed a modified fragrance glue to produce a typical smell which attracts only insects and then captures them at once. By using this innovative method, the use of chemicals such as pesticides could be avoided and an organic mushroom product could be grown, drawing much market attention.

The most important technological innovation of AAC is the incremental of efficient and mature processing of baglog by optimizing time and material composition of baglog production. The process is efficient because its baglog production is faster than that of other enterprises, and it is mature because baglog production overall has a failure rate of only about $2 \%$ (1 baglog has an average yield of $0.35 \mathrm{~kg}$ fresh mushroom), with a $99 \%$ capability of yielding first grade fresh mushroom. Thus, AAC can produce fresh mushroom at a cheaper rate and the baglog technology become much more reliable. For example, AAC's baglog technology is ready to produce mushroom in day $30^{\text {th }}$ until $35^{\text {th }}$, whereas the average time is 40 to 45 days. AAC even could sell baglog at price of $1500 \mathrm{IDR} /$ item which nearly 500 IDR cheaper than common producers. When the standard baglog composition is occasionally modified to accelerate production, ACC uses only the standard composition. 


\subsubsection{Organizational Innovation (new organization)}

AAC has been established, owned, and managed by a former farm manager who used to work for a big shiitake mushroom enterprise. After resigned his job, in 2003, he built his own enterprise in Cianjur district. Now AAC also copes the member as the farmer.

The organization of AAC is consimilar to contract farming, developed since 2004, and keep evolved to 30 members. Contract farming is an agreement between enterprise and farmers for the production and supply of agricultural product under several agreement and predetermined prices. The agreement comprises input supply, technical advice and commitment of farmers to provide specific commodity in quantities and quality standard (Eaton \& Shepherd, 2001). This AAC's organization aims to enhance the quantity of mushroom production jointly by utilizing local resource as mushroom farmer. Therefore, AAC created contract farming agreement with farmers as the member in 3 main points which adjusted with local condition and institution.

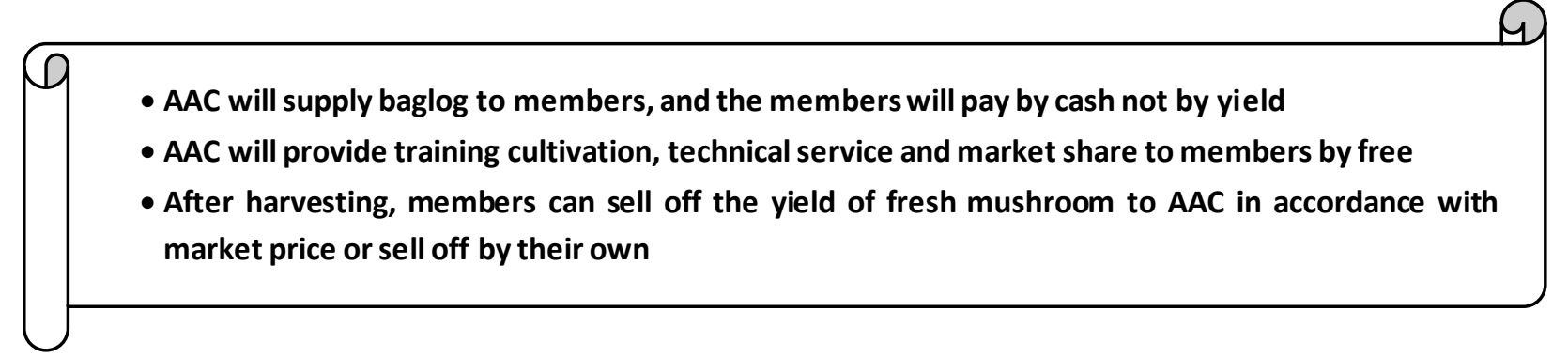

Figure 2. Contract agreement of AAC with members

The contract farming agreement which has been made is not exactly the same as general contract farming since the agreement said that farmers or members have no commitment back to AAC to provide specific commodity (fresh mushroom product). This is the main point of their organizational innovation. By reliable baglog technology, market's profit and assurance, affordable capital and the contents of contract agreement, AAC become the first mushroom enterprise in Indonesia to successfully implement such an organization. The number of members continue to increase because not only supervision support, but also when the new members faced marketing problem, AAC is able to accommodate. An additional benefit of this organization is that of the social support brought in by members who maintained harmony with the local society and neighbors as well as the security efforts.

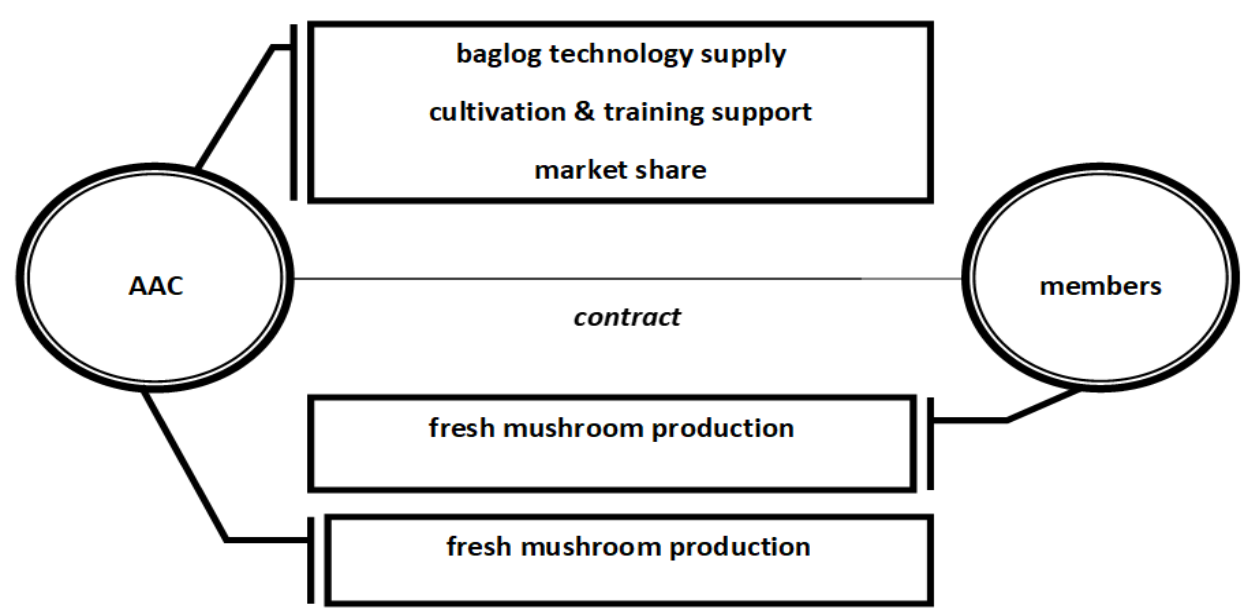

Figure 3. New organization of AAC 


\subsection{ACC's system of innovation}

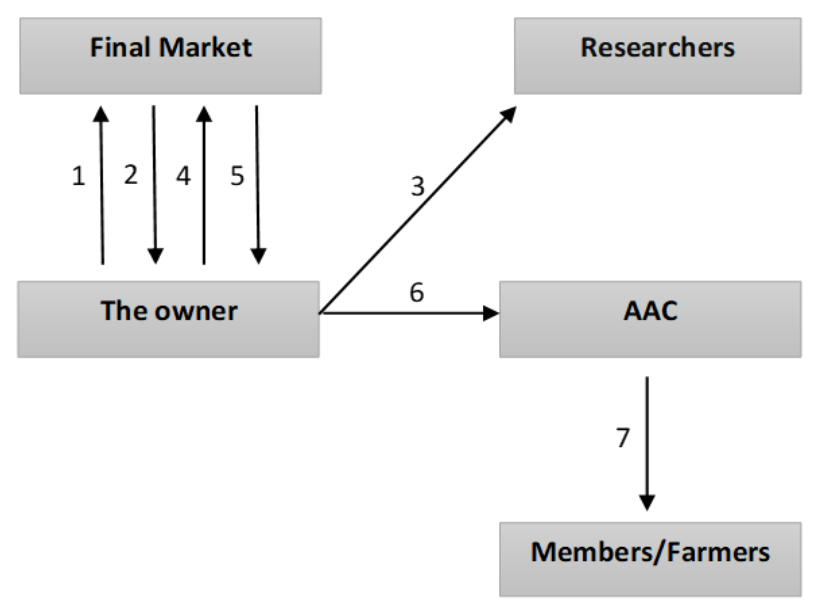

Figure 4. Innovation phase of AAC

Description:

1. Starting business and initial marketing in 2001, produced $5 \mathrm{~kg}$ mushroom/day, supported by one labor

2. There were still market rejection

3. Making a strategy for supplying a cheaper mushroom by doing some experiments of baglog

4. Entering market with new mushroom product

5. Obtaining consumer and final market preference, and the demand is increased

6. In 2003, the owner built the enterprise of AAC in lease land, and need more labors

7. In 2004, the demand was increasing highly, AAC collaborated with the farmers and established a new organization

\subsubsection{Actors and Networks}

This first section explains the role of the actors in innovation and their networking. These actors could be organizations or individuals. Howe ver, the enterprise is a key actor in technological system. Networking can be divided into two types, the non-market type, relating to supply of knowledge and material supply, and the market type, relating to demand. Actors in this system consist of 5 actors (AAC, researchers, farmers, suppliers, and final market).

AAC innovation system exactly is started when AAC had difficulty to penetrate existing markets. Although mushroom market was already existed in Cianjur distric, it was very difficult to sell mushroom to them in the final market because each retailers have their own producers plus distrust of newcomer especially in traditional market which is a favorite place for Indonesian people to shop vegetables. To overcome this challenge, the owner as the mastermind of AAC applied a strategy of supplying cheaper mushroom that appeared better than the mushroom of other producers. He needed to create more reliable baglog technology with superior yield performance.

From his work experience, he realized that there were many drawbacks with the baglog production process which should be addressed. Incremental innovations are very important for improving the efficiency of all factors of production (Geels, 2005). However, research evidence indicated the skill constraints of small business and its impact on its ability to innovate (Freel, 1999). Dickson and Hadjimanolis (1998) stated that,

"Since small enterprises typically lack some of the essential resources for innovation, such as specialist skills and research equipment, they have to acquire them from external sources, such as other enterprises, technical institutions, etc".

The owner was aware with those condition and therefore sometimes he sought and maintained the expert assistance from public research institute to obtain new science input about mushroom science. During almost 1.5 month, the owner conducted his small experiments. Input from researchers were necessary to determine the boundary of experiments, because if failed, it would spent much cost which should be able used in real production. This condition might be not able tolerated by small enterprise. After all, he acquired the knowledge and claimed that the experiment knowledge was parallel with his hypotheses. He concluded a formula and said that the excessive of time and some material composition 
in baglog production process has no significant impact and instead consume much more cost and time as well as would reduce the quality of baglog. Thus, AAC were able to cut production cost, accelerate production time and upgrade baglog technology for producing a better quality of fresh mushroom. Furthermore, by own effort, AAC also made fragrance glue using existed insect glue and then combined with other fragrance material to against insect attack without using chemical material or pesticide.

In the non-market type, the personal relationships between the owner and researchers from the public research institute are tied to the exchange of knowledge and information. This personal relation was needed to help the owner in upgrading his baglog performance. The relation was formed by the owner with his old acquaintance from public research institute. This type of personal relationship seems to be preferred as it was said easier and simpler than institutional relationship especially when they came from public research institute. Failure of communication with research institutions due to complexities of access arising from bureaucratic and administrative processes become a very serious issue (Fontana et al., 2006).

Suppliers have a role in supplying raw material for baglog production, for example sawdust as primary composition from lumber industry. As these are waste of industry, there were no charge of them due to mutual business relation. However, in subsequent time of production, the suppliers could not comply AAC's high demand which only came from industrial waste. Sawdust has become distinctive business of the lumber industry. Sawdust business is the co-transition condition where the transition of main business has affected and issued other business.

In the market-type, high demand from final market stimulates the organization innovation. After AAC succeed to produce a cheaper fresh mushroom by evaluating the process of baglog production, AAC started over to market the fresh mushroom product to retailers in traditional market and even directly to consumers. Their mushroom gained consumer's preference then market attention. The organic aspect of their mushroom also become supportive aspect in gaining consumer's preference. Gradually AAC received much demand from final market such as retailer and even wholesaler who come from Cianjur to other town around West Java. The owner confessed that so far even at AAC's scale now, they are not be able to fulfill all demand. Around 1 year after established, AAC has limited capacity to produce baglog and conduct the cultivation in order to comply final demand. Therefore, the idea of collaborating (as if contract farming) with the local society who are partly engaged in farming was emerged. Mushroom production would give employee and business opportunities for youth and mid-age people in rural area especially in developing countries (Celik \& Peker, 2009). Celik and Peker (2009) also represent the circumstance of mushroom business where despite it seems to be professional work, it was observed that mushroom business are managed by the people at low level education in rural area, and they need short training on mushroom production. The other problem observed by AAC was, despite local society has been familiar with mushroom cultivation, mushroom farming has no association or aggregation so that each farmer work independently with their business and their problems. AAC proposed their contract farming or joint farming with the society under supervision benefits towards cultivation equipment and supplies, mushroom baglogs, and mushroom cultivation training to achieve optimal production. Their contract farming is proposed by the strategy of local champion where one party was created as a model to attract others respect, and the strategy of feasibility study which can be shown to new candidates (see table 2). Their contract farming was also adjusted with local institution to reach a wide range of candidates. By now, 30 parties already joined with AAC as members where each members have approximately $30.000-100.000$ baglogs with overall production of members reach $1000 \mathrm{Kg} /$ day. As shown on Table 2, return of investment is short and will be paid off after the second cycle.

Table 2. Sample result of feasibility study for new candidate of mushroom farmer

\begin{tabular}{lllll}
\hline Scale & $\begin{array}{l}\text { Investment } \\
(\mathrm{IDR})\end{array}$ & $\begin{array}{l}\text { Gross income } \\
(\mathrm{IDR} / \mathrm{cycle})\end{array}$ & $\begin{array}{l}\text { Cost } \\
(\mathrm{IDR} / \mathrm{cycle})\end{array}$ & $\begin{array}{l}\text { Net income } \\
(\text { IDR/cycle })\end{array}$ \\
\hline $\begin{array}{l}\text { Small scale } \\
(5,000 \text { baglogs })\end{array}$ & $5,640,000$ & $12,687,500$ & $9,020,833$ & $3,666,667$ \\
$\begin{array}{l}\text { General scale } \\
(20,000 \text { baglogs })\end{array}$ & $18,620,000$ & $50,750,000$ & $39,036,111$ & $11,713,889$ \\
\hline
\end{tabular}

Source : Primary data of feasibility analysis by fixed assumptions in 2012 (the most up to date archieve)

(IDR = Indonesian currency; 1 cycle $=4$ to 5 months ; mushroom selling price $=7,250 \mathrm{IDR} / \mathrm{kg}$ )

4.2.2 Institutions

Institutions consist of the customs, established practices, or standards influencing the actions of actors in the system. This second section describes further the character of the owner, the researchers and the members as the main actors in 
the innovation system. In the system, AAC is the key player, but the owner acts as mastermind or primary agent of the enterprise. Within his small enterprise, the owner acts as general manager without the complexities of hierarchy and ex-research custom based on owner's experience gives AAC high flexibility to respond to changing. As the control functions are directly managed by the leader, new techniques for the growth and development of innovation can more easily be considered (Nada et al., 2012). When the uncertainty is high, organizations should interact more to gain new knowledge from the others (Tidd et al., 2005). Researchers from public research institute gave an important knowledge input for the owner in enhancing baglog technological aspect. The owner prefers to them of public institution for some considerations in which they are reachable in personal. They carry out public service to society and industry so that they are overt and easier to be discovered than whom of private institution.

In organizational innovation, farmers as members are important actors to the implementation of the strategy. AAC is located in rural area, and most of the surrounding local people have a profession as farmer such as rice farmers and mushroom farmers. The people probably have the same custom and routine as farmer, but they have different standard towards mushroom cultivation. The attractiveness of mushroom farming lies on its simplicity of cultivation method than that of other farming. Rice farming is indeed complex and high risk but the market are vast. Those who have ne ver entered into mushroom farming generally have no access into mushroom market, whereas the motivation behind the decision of farmers to engage in contract farming is, to obtain such advantages as market access and technical assistance (Guo et al., 2005 ; Masakure \& Henson, 2005). Particularly when taking a new farming, farmers faced the risk of both market failure and production problems (Eaton \& Shepherd, 2001). In the next situation, mushroom farmers certainly have market access and what they considered actually only technical assistance to boosting production. Therefore, besides technical assistance, AAC made an adjustment with the agreement of their contract farming (organization) to be more open and flexible which mean that AAC do not have a full control to market access and the members do not have to give the supply of fresh mushroom product to AAC. AAC will provide the market access for the members who have no market access, contrariwise the others can sell off to their own market. This adjustment helpfully drags plentiful members as producer could avoid the prejudice of monopoly position and unreliable quotas allocation due to market control.

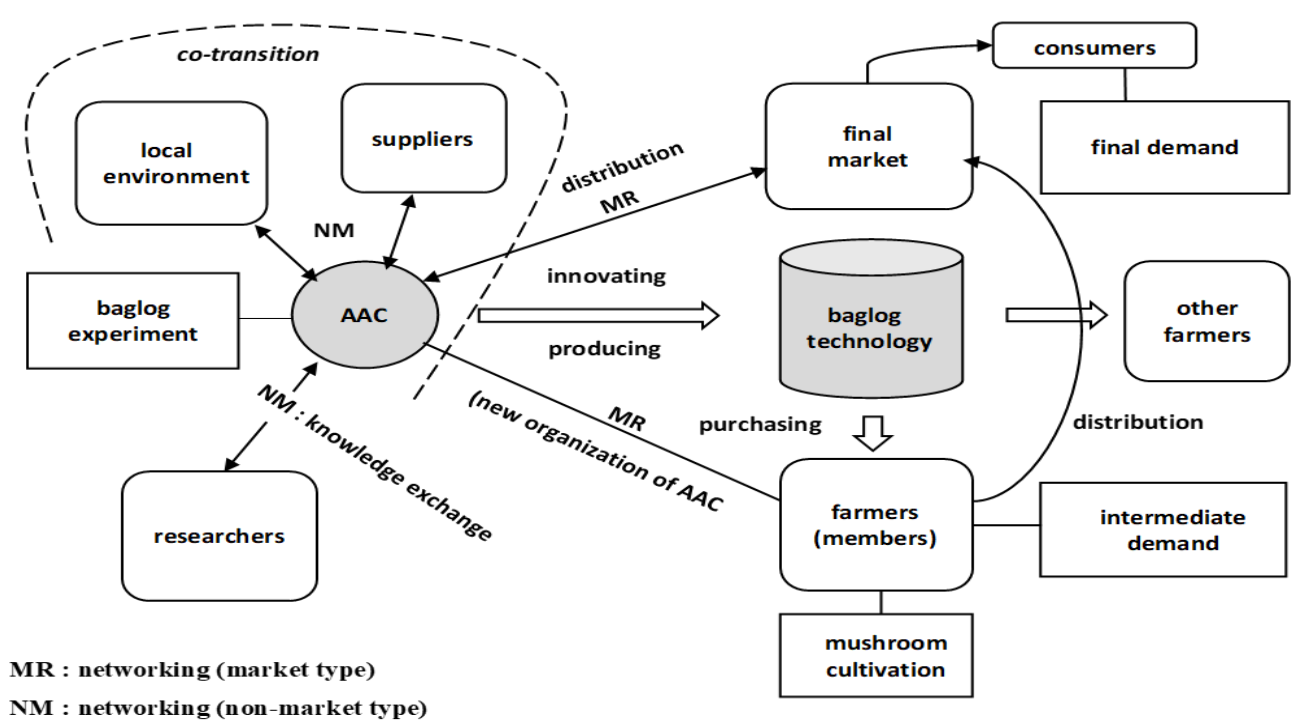

Figure 5. Innovation and business system of AAC

\section{Conclusion}

AAC reveals two types of strategies, one relating to the technological part, and the other relating to the organization part. The technological focuses on attracting the final market with cheaper and better quality of fresh mushroom product. This aspect was achieved by the owner who indeed has had sufficient knowledge and experience about mushroom science. The organization part focuses on developing capacity to fulfill the demand. The way of organization intends to increase quantities of fresh mushroom product jointly with the potential local society by adjustable contract farming. Technical assistance and market access are still the principal provision of organizational strategy. However, the agreement of the contract must be adjusted without monopoly action to farmers. Indonesian society's awareness of health benefits of mushroom has resulted in the positive growth and the demand is still higher than the supply. Contract 
farming or joint farming or other forms of collaboration could be a positive alternative way to intensify the business performance and to escalate the scale of production especially between producers and farmers. Producers may overcome land constraint, on the other side farmers are secure from market and production failure.

The strategies of AAC were capable of being successful innovation by interacting and cooperating with external sources such as researchers from public research institute, farmers, suppliers, final market and surely consumer as final demand. This study can be improved by combining standpoint and perspective's data from other respondents such as researchers, retailers and consumers to acquire more comprehensive understanding.

\section{References}

Amuneke, E. H., Dike, K. S., \& Ogbulie, J. N. (2011). Cultivation of Pleurotus ostreatus: An edible mushroom from agrobase waste products. Journal of Microbiology and Biotechnology Research, 1(3), 1-14. Retrieved from https://www.jmbronline.com/index.php/JMBR/article/view/27/27

Arminsyurita. (2014). Analisis Strategi Pemasaran Jamur Rimba Jaya Mushroom. Jurnal Ilmiah Ilmu Administrasi, 6(2). Retrieved from

https://www.google.co.jp/url?sa=t\&rct=j\&q=\&esrc=s\&source=web\&cd=1 \&cad=rja\&uact=8\&ved=0ahUKEwidj Ib Mr8jTAhUHE7wKHb2xAVYQFggjMAA\&url=http\%3A\%2F\%2Fwww.stiami.ac.id\%2Fjurnal\%2Fdownload\%2F1 23\%2Fanalisis-strategi-pemasaran-jamur-rimba-jaya-mushroom\&usg=AFQjCNHi83s_MvvVIn0xuSk0olURdFba Dw\&sig2=-UHPip0CQhktp1DyQa_yFQ

Carlsson, B., \& Stankiewicz, R. (1991). On the nature, function and composition of technological systems. Journal of Evolutionary Economics, 1, 93-118. https://doi.org/10.1007/BF01224915

Celik \& Peker. (2009). Benefit/Cost Analysis Of Mushroom Production For Diversification Of Income In Developing Countries. Bulgarian Journal of Agricultural Science, 15(3), 228-237. Retrieved from http://www.agrojournal.org/15/03-07-09.pdf

Dickson, K. E., \& Hadjimanolis, A. (1998). Innovation and Networking amongst Small Manufacturing Firms in Cyprus. International Journal of Entrepreneurial Behaviour \& Research, 4(1), 5-17. https://doi.org/10.1108/13552559810203939

Eaton, C., \& Shepherd, A.W. (2001). Contract Farming, Partnership for Growth. FAO Agricultural Services Bulletin. https://books.google.co.jp/books?hl=ja\&lr=lang_en\%7Clang_ja\&id=K7qM_i8yj1sC\&oi=fnd\&pg=PR3\&dq=joint +farming\&ots=jb09wmG011 \&sig=zH1-kHDLDahmYMHY18VDcL_VN0A\#v=onepage\&q=joint\%20farming\&f= false

Fontana, R., Geuna, A., \& Matt, M. (2006). Factors Affecting University-Industry R\&D Projects: The Importance of Searching, Screening and Signalling. Research Policy, 35, 309-323. https://doi.org/10.1016/j.respol.2005.12.001

Food and Agriculture Organization of the United Nations (FAOSTAT). (1961 - 2014). Production quantities of Mushrooms and truffles in Indonesia. Retrieved February 2, 2017, from http://www.fao.org/faostat/en/\#data/QC/visualize

Freel, M. S. (1999). Where are the Skills Gaps in Innovative Small Firms? International Journal of Entrepreneurial Behaviour \& Research, 5(3), 144-154. https://doi.org/10.1108/13552559910371095

Geels, F. W. (2005). Technological Transitions and System Innovations A Co-Evolutionary and Socio-Technical Analysis. UK: Edward Elgar Publishing Limited. https://doi.org/10.4337/9781845424596

Guo, H., Jolly, R. W., \& Zhu, J. (2005). Contract Farming in China: Supply Chain or Ball and Chain? 15th Annual World Food \& Agribusiness Symposium, IAMA, Chicago.

Badan Pusat Statistik Kabupaten Cianjur. (2015). Kabupaten Cianjur Dalam Angka 2015. Retrieved from https://cianjurkab.bps.go.id/new/website/pdf_publikasi/Kabupaten-Cianjur-Dalam-Angka-2015.pdf

Iriantinah, C. (2014). Strategi Pengembangan Komoditas Jamur Tiram Putih (Pleurotus Florida) Di Kabupaten Nganjuk. Jurnal Manajemen Agribisnis, 14(2).

Kementerian Pertanian. (2015). Statistik Produksi Holtikultura. Direktorat Jenderal Holtikultura. Retrieved from hortikultura.pertanian.go.id/wp-content/uploads/2016/02/Statistik-Produksi-2014.pdf

Marshall, E., \& Nair, N. G. (2009). Make money by growing mushrooms. Food and Agriculture Organization (FAO) of The United Nations, Rome. Retrieved from http://www.fao.org/3/a-i0522e.pdf

Masakure, O., \& Henson, S. (2005). Why do small-scale producers choose to produce under contract? Lessons from non-traditional vegetable exports from Zimbabwe." World Development 33(10), 1721-1733. 
https://doi.org/10.1016/j.worlddev.2005.04.016

Nada, N., Ghanem, M., Mesbah, S., \& Turkyilmaz, A. (2012). Innovation and Knowledge Management Practice In Turkish SMEs. Journal of Knowledge Management, Economics and Information Technology, 2(1), 248-265. Retrieved from http://www.scientificpapers.org/wp-content/files/15_1259_Nader_Nada_INNOVATION_and_KNOWLEDGE_M ANAGEMENT_PRACTICES_IN_TURKISH_SMEs.pdf

Nugroho, Y. (2013). Analisis SWOT Terhadap Strategi Pengembangan Bisnis Budidaya Jamur Tiram, Studi Kasus di Perusahaan Jamur di Kabupaten Bogor. Electronic Theses and Dissertations, Gadjah Mada University. Retrieved from

http://etd.repository.ugm.ac.id/index.php?mod=penelitian_detail\&sub=PenelitianDetail\&act=view\&typ=html\&buk u_id $=65678$

Rozmiza, M. Z., Davies, W. P., Rozniza, A. C. R., Jabil, M. J., \& Mazdi, M. (2016). Prospects for Increasing Commercial Mushroom Production in Malaysia: Challenges and Opportunities. Mediterranean Journal of Social Sciences, 7(1). https://doi.org/10.5901/mjss.2016.v7n1s1p406

Schilling, M. A. (2012). Strategic Management of Technological Innovation 4th Edition. McGraw-Hill/Irwin.

Schumpeter, J. A. (1934). The Theory of Economic Development. Cambrige, Harvard University Press.

Tidd, J., Bessant, J., \& Pavitt, K. (2005). Managing Innovation: Integrating Technological, Market and Organizational Change. Chichester and New York, NY: J. Wiley.

\section{Copyrights}

Copyright for this article is retained by the author(s), with first publication rights granted to the journal.

This is an open-access article distributed under the terms and conditions of the Creative Commons Attribution license which permits unrestricted use, distribution, and reproduction in any medium, provided the original work is properly cited. 